DOI 10.37882/2223-2982.2020.12.03

\title{
МУЗЕЙНАЯ ПЕДАГОГИКА И ЕЕ ОБРАЗОВАТЕЛЬНЫЕ ВОЗМОЖНОСТИ В РАЗВИТИИ ОБЩЕКУЛЬТУРНОЙ КОМПЕТЕНЦИИ ВОСПИТАННИКОВ ПЕНИТЕНЦИАРНЫХ УЧРЕЖДЕНИЙ
}

\section{MUSEUM PEDAGOGY AND ITS \\ EDUCATIONAL OPPORTUNITIES \\ IN THE DEVELOPMENT OF GENERAL CULTURAL COMPETENCE OF INMATES OF PENITENTIARY INSTITUTIONS}

A. Andriyanov

Summary: The article examines the pedagogical, cultural and educational significance of museums, describes their positive impact on the level of culture and education of the people. The purpose of this study is to study the formation of the cultural and educational potential of a pupil of penitentiary institutions through the means of museum pedagogy. In the course of the study, it was found that with the help of museum pedagogy, the main goal of punishment is achieved - the correction of convicts by increasing general cultural competence and spiritual and moral development.

Keywords: museum, museum pedagogy, inmates of penitentiary institutions, educational opportunities, general cultural competence.
$\mathrm{H}$ а сегодняшний день социокультурная сфера современного музея приобретает индивидуальный, личностный характер, в основе которого лежит интериоризация культурного пространства музея через эмоциональное восприятие и интеллектуальное понимание. В музейно-образовательной среде все построено на интересе, свободном выборе, позиции посетителя. Используя современные педагогические технологии, музей может и должен решать воспитательные задачи. В последнее время появилась тенденция использования музейной педагогики и ее образовательных возможностей для развития общекультурной компетенции воспитанников пенитенциарных учреждений [1].

Главной формой уголовного наказания в современном мире, как известно, является лишение свободы в виде тюремного заключения. В условиях изоляции от общества, лишения определенных прав и свобод, личность преступника изменяется, переоцениваются многие привычные для него ценности. Несмотря на все предпринимаемые усилия, у воспитанников пенитенциарных учреждений возникают серьезные проблемы социальной адаптации. Решить их, по мнению ученых-пенитенциа-

\author{
Андриянов Андрей Викторович \\ Аспирант, Пермский Государственный \\ Гуманитарно-Педагогический Университет \\ andrei-a1983@yandex.ru
}

Аннотация: В статье исследуется педагогическое и культурно-воспитательное значение музеев, описывается их положительное влияние на уровне культуры и образования народа. Целью данного исследования является изучение формирования культурного и образовательного потенциала воспитанника пенитенциарных учреждений посредством средств музейной педагогики. В ходе исследования установлено, что с помощью музейной педагогики достигается главная цель исполнения наказания - исправление осужденных путем повышения общекультурной компетенции и духовнонравственного развития.

Ключевые слова: музей, музейная педагогика, воспитанники пенитенциарных учреждений, образовательные возможности, общекультурная компетенция.

ристов, призвана работа, направленная на ресоциализацию лиц, находящихся в местах лишения свободы [2].

Одной из важнейших задач пенитенциарной педагогики является исправление осужденных. Исправление - противоречивый процесс изменения сложившихся стереотипов сознания и поведения осужденных, представляющий собой целенаправленное, а иногда и жесткое управление их жизнедеятельностью. Исправление выступает как цель и результат перевоспитания и как процесс самовоспитания, саморазвития личности [3]. Степени изменения личности вполне сопоставимы с общечеловеческими нормами, поскольку не существует отдельно взятой морали для правонарушителей и для законопослушных граждан. Но в процессе исправления такие нравственные нормы, как добросовестное отношение к своим обязанностям, труду, уважение к правилам пенитенциарного учреждения, бережное отношение к общественной и личной собственности приобретают статус правовых.

Процесс перевоспитания осужденных в колониях для несовершеннолетних является сложным и много- 
плановым. Наряду с факторами дисциплины, которым является для несовершеннолетнего осужденного режим содержания, интеллектуального развития и профессионального самоопределения не менее весомую роль играет нравственно-эстетическое воспитание. Именно этот аспект воспитания часто оказывается упущенным [4].

Находящиеся в следственном изоляторе и отбывающие срок заключения граждане по понятным причинам ограничены в передвижениях и лишены возможности посещения музеев и иных культурных центров. Однако тенденция к гуманизации положения заключенных и развитие пенитенциарной психологии побуждает органы исполнения наказаний задумываться о воспитательном значении музейного дела [5].

В настоящее время музей является одним из самых доступных культурных учреждений. Музей совмещает в себе функции исследовательского центра, учебного заведения, места для отдыха и места для массовых мероприятий. Эта многофункциональность делает современный музей особенным местом для посещения.

В настоящее время музей - социальный институт, который:

а) расширяет и дополняет деятельность всесторонней школы;

б) вовлекает музейного педагога, гида и посетителя в единую межпредметную область связи;

в) активно реализует свой культурно-образовательный потенциал [6].

Сегодня объективно важно использовать социальные и культурные ресурсы музея для нравственного воспитания не только подрастающего поколения, но и воспитанников пенетенциарных учреждений.

С этой целью в основу деятельности музея положены следующие принципы:

- Формирование активной гражданской позиции;

- Утверждение патриотических ценностей и идеалов;

- Воспитание и уважение к старшему поколению, к его боевым и трудовым подвигам;

- Формирование у воспитанников пенитенциарных учреждений объективного подхода к событиям в жизни страны;

- Привлечение воспитанников пенитенциарных учреждений к поиску материалов и экспонатов и на этой основе пополнение и создание новых экспозиций;

- Увековечивание памяти участников Великой Отечественной войны;

- Пробуждение интереса к истории Родного края;

- Проведение в музее торжественных акций, посвященных памятным датам в истории нашей Роди- ны, тематических занятий, уроков, с использованием материалов и экспонатов музея [7].

В западных странах музейные программы для заключенных постепенно вводятся в регулярную практику. Лувр устраивает передвижные выставки репродукций своих шедевров для заключенных, которые имеют хорошее поведение. При тюрьме Фелтхэм действует художественный кружок, в котором заключенные создают работы декоративно-прикладного искусства под влиянием полотен старых мастеров.

С 1971 г. при Бутырской тюрьме (Следственный изолятор № 2 УФСИ России по г. Москве) действует внутренний «корпоративный» музей в Пугачевской башне бывшем отделении для политических заключенных. Аналогичные музеи действуют в других исторических тюрьмах - в изоляторе «Кресты» (Санкт-Петербург) и во Владимирском централе, в ИК-2 (Казань). Свои «комнаты истории» открыты в некоторых региональных подразделениях ФСИН. Подобные музеи, как правило, закрыты для внешних посетителей (либо посещение строго регламентировано) и предназначены для сотрудников органов исполнения наказания, а также журналистов. Потенциал для работы с заключенными задействован в малой степени [8].

В материалах опыта Бийской воспитательной колонии по нравственному воспитанию, приобщению подростков к художественной культуре представлены формы нравственно-эстетического воспитания несовершеннолетних осужденных, проводимые педагогами школы колонии совместно с народным литературным музеем имени В.М. Шукшина.

Литературный музей был основан по инициативе педагога колонийской школы А.С. Пряхиной в 1983 году, ставшей его директором. В 1994 г. музею назначен титул народного. За годы существования музей стал частью жизни школы. Эта нетрадиционная форма работы хорошо зарекомендовала себя, так как подростки приобщаются к творчеству великого земляка, а также - к миру прекрасного, к вечным ценностям.

Большая роль музея в эстетическом воспитании - под воздействием музея совершается нравственный рост воспитанников, попавших в трудную жизненную ситуацию, переосмысливание своего отношения к жизни и находящимся вокруг людям. Воспитанники становятся передовиками учебы и производства. Как правило, члены Совета музея освобождаются условно-досрочно.

Также в музее проведены сотни классных часов, организованы десятки экскурсий лучших учащихся по Шукшинским местам города, нередко проводимые совместно с родителями воспитанников. Эти экскурсии стали одной из нетрадиционных форм поощрения воспитанников колонии за хорошую учебу и примерное по- 
ведение.

С 1979 года в Бийской воспитательной колонии проходят малые Шукшинские чтения, собирающие гостей из разных уголков страны, на которых наравне с известными писателями и актерами, выступают воспитанники колонии.

Силами воспитанников оформлены альбомы, отреставрированы экспонаты, изготовлены макеты дома матери Шукшина, электрифицирован стенд «Шукшинские адреса на карте мира».

Результатом исследовательской работы и переписки с учеными из астрофизической обсерватории стали материалы о планете «В.М. Шукшин», найдены исторические сведения о теплоходе с одноименным названием. Итогом многолетней работы стала книга основателя музея Пряхиной А.С. «Родословная В.М. Шукшина».

На протяжении многих лет музей остается одним из центров воспитательной работы колонии, формирующих у воспитанников не просто интерес к творчеству их знаменитого земляка, но и чувство гордости за то, что их руками продолжает создаваться первый народный литературный музей имени В.М. Шукшина.

Изучая творчество и личность писателя, несовершеннолетние осужденные учатся отличать хорошее от дурного, оценивать свои поступки глазами окружающих, обретают веру в себя.

Нравственное и патриотическое воспитание в воспитательной колонии призвано выработать у осужденных активную жизненную позицию, преодолеть и предупредить у воспитанников различные отклонения от норм общественной морали, проявления безнравственности, развить в подростках чувство гражданского долга, любовь к Родине, готовность ее защищать [9].

Походы в музеи создают для положительно характеризующихся осуждённых с целью культурно - нравственного и патриотического воспитания. К примеру осужденные, отбывающие наказание в мурмашинской колонии-поселении ИК-18, посетили Мурманский областной краеведческий музей.

Экскурсанты посмотрели практически все выставки и экспозиции музея. Максимальный интерес побудил выставочный зал, в коем показана флора и фауна Кольского полуострова. Впечатление на осужденных совершила и экспозиция, приуроченная к героической обороне Заполярья в годы Великой Отечественной войны.

По словам старшего инспектора группы воспитательной работы с осуждёнными регионального УФСИН Андрея Андреева, культпоход организован для положительно характеризующихся осуждённых с целью куль- турно - нравственного и патриотического воспитания.

Аналогичные акции по инициативе офицеров-педагогов проходят в УФСИН не в первый раз. До этого краеведческий музей уже посещала группа осуждённых участка колонии-поселения ИК-17 [10].

Посещая музей, воспитанники пенитенциарных учреждений чувствуют глубину и разнообразие современного музейного мира, созданного людьми и для людей. Педагогические, методические и воспитательные преимущества данного заведения трудно переоценить. Коллекции и экспозиции показывают настоящую образовательно-интеграционную сущность народного творчества. Целенаправленная музейно-просветительская деятельность готовит основу для дальнейшего личного развития и способствует более высокому творчеству. Экскурсии, тематические семинары и открытые уроки, организованные в музейно-образовательном пространстве, позволяют воспитанникам пенитенциарных учреждений ознакомиться с русскими культурными традициями. Музейные коллекции и экспозиции придают уникальную возможность изучить творческие методы, технологии производства и исторические шедевры, а также сформировать собственную культурно-историческую позицию [11].

Таким образом, музейная педагогика представляет собой гармоничное единство всех образовательных и социокультурных достижений, обогащающих и удовлетворяющих потребности и интересы человека, она стимулирует развитие очевидных и скрытых творческих качеств, вовлекающих человека в процесс осмысления и воспроизведения духовных ценностей.

Исследования показывают, что методологические основы музейной педагогики гармонично объединяют фундаментальные принципы педагогической философии и специфику музейно-просветительского пространства. Также определено, что музейная педагогика как научная дисциплина учитывает особенности современного музея, где создается уникальная объектно-космическая среда и формируется на основе открытых культурно-цивилизационных диалог и взаимодействие с объектами духовного наследия. Поэтому приобретение и осмысление новых сложных идей музейной педагогики приводит к определенным стимулирующим, коррекционным, реабилитационным и оздоровительным эффектам [12].

Можно сделать вывод, что вовлечение заключенных в музейную жизнь - тяжелая практика, так как приходится преодолевать как сопротивление самой тюремной среды, так и многочисленные институциональные ограничения. Однако заметен интерес к этой теме, начальные эксперименты в этом направлении достаточно результативны и, вероятно, повлияют на пенитенциарную систему в будущем. 


\section{ЛИТЕРАТУРА}

1. Артюхова Е.С. Основные направления в формирования духовно-нравственной личности // Муниципальное образование: инновации и эксперимент. 2012. № 3. C.26-28.

2. Mori R.C. (2016). Dermeval Saviani's thought and education in science museums. Educ. Pesqui., 42(2). Date View May 15, 2017 http://dx.doi.org/10.1590/S15179702201604144612.

3. Xanthoudaki M. Museums, innovative pedagogies and the twenty-first century learner: a question of methodology. Museum \& Society, 2015 , - №13 (2), $247-265$.

4. Юсова М.Б. Организация деятельности психологических служб, их роль в учреждениях уголовно-исполнительной системы России // Прикладная юридическая психология. — 2011. — № 1. — С. 193-196.

5. Юсова М.Б. Пути повышения эффективности деятельности психолога-практика уголовно-исполнительной системы // Прикладная юридическая психология. — 2011. — № 3. - С.147-155.

6. Демидова, Е.М. Роль музея как образовательного учреждения в формировании социокультурных компетенций у студентов / Е.М. Демидова. Текст : непосредственный // Педагогика: традиции и инновации : материалы VI Междунар. науч. конф. (г. Челябинск, февраль 2015 г.). — Челябинск : Два комсомольца, 2015. - С. 39-41.

7. Долгачева Е.А. Новое время для школьного музея // Эксперимент и инновации в школе. 2011. № 1. С.46-48.

8. Клепиков В.Н. Духовно-нравственное воспитание в урочной и внеурочной деятельности // Муниципальное образование: инновации и эксперимент. 2013. № 1. C.44-50.

9. Клепиков В.Н. Интеграция образования в контексте духовно-нравственного воспитания школьников // Муниципальное образование: инновации и эксперимент. 2013. № 5. С.13-18.

10. Клепиков В.Н. Потенциал социокультурной модернизации образования в ракурсе нравственно-этического воспитания детей, подростков и молодёжи // Муниципальное образование: инновации и эксперимент. 2013. № 3. С.39-46.

11. Колокольникова 3.У., Лобанова 0.Б., Яковлева Е.Н. Формирование культурно-просветительской компетентности будущего учителя посредством музейной педагогики // Образование и наука. 2013. № 2. С.147-163.

12. Постникова И.М., Жиркова Н.А., Фирсова Е.С. Культурно-образовательная среда села // Муниципальное образование: инновации и эксперимент. 2011. № 5. C.46-48.

(с) Андриянов Андрей Викторович (andrei-a1983@yandex.ru).

Журнал «Современная наука: актуальные проблемы теории и практики»

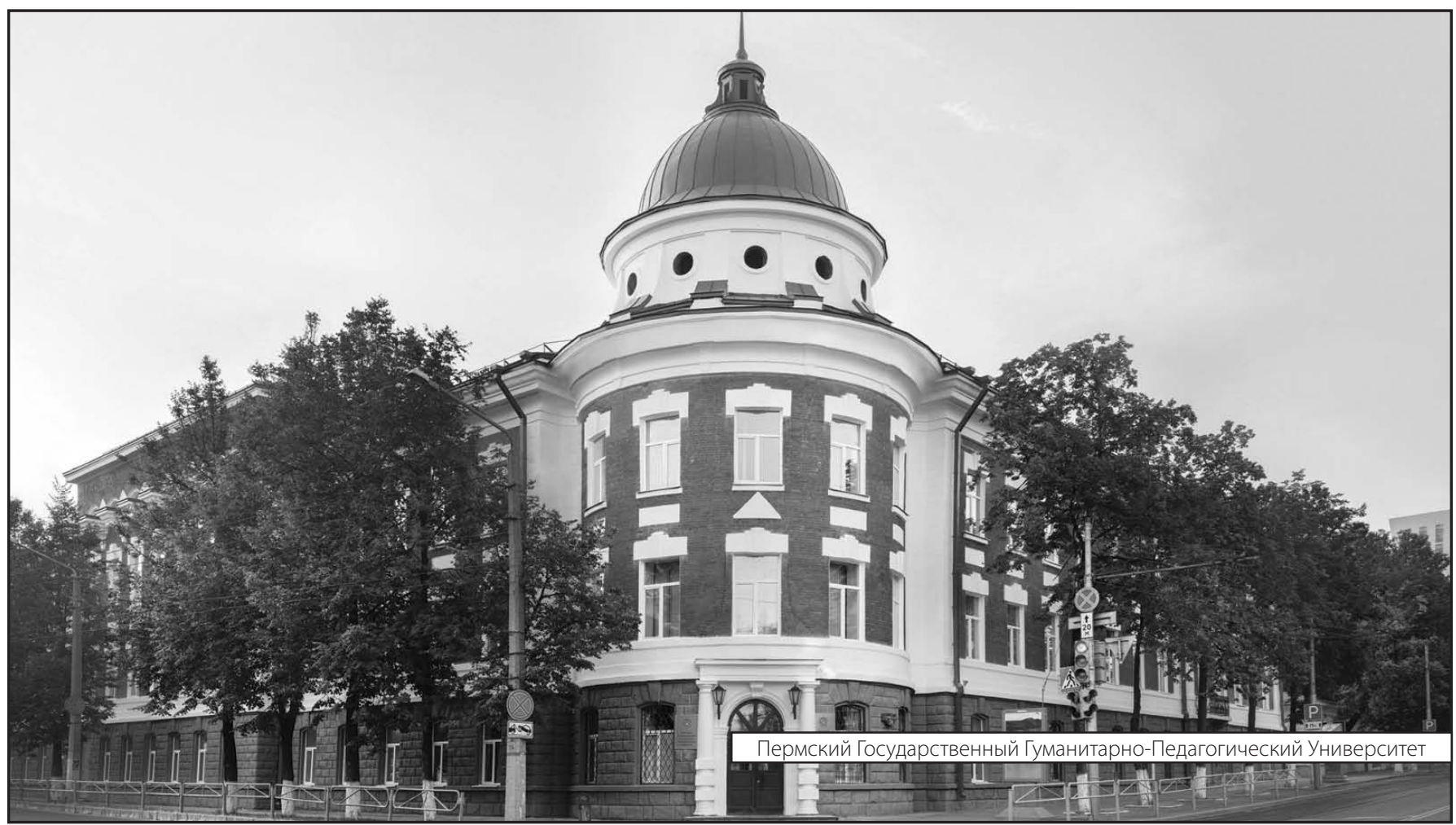

